\title{
Analysis of oxidative DNA damage / oxidative stress markers in patients with ovariancancer
}

\author{
Krzysztof Roszkowski \\ Department of Radiotherapy, the F. Lukaszczyk Oncology Center, Bydgoszcz, Poland
}

Email address:

roszkowskik@co.bydgoszcz.pl

\section{To cite this article:}

Krzysztof Roszkowski. Analysis of Oxidative DNA Damage / Oxidative Stress Markers in Patients with Ovarian Cancer.American Journal of Clinical and Experimental Medicine. Vol. 1, No. 2, 2013, pp. 40-43. doi: 10.11648/j.ajcem.20130102.12

\begin{abstract}
Although the role of oxidative stress in the process of carcinogenesis seems well known, the quantitative correlation between oxidative DNA damage and the degree of histological malignancy of a neoplasm has not yet been determined. In the present study we attempted to show the possible correlations by looking at the amounts of the basic oxidative stress markers 8-oxoGua (8-oxo-7.8-dihydroguanine) and 8-oxodG (8-oxo-7.8-dihydro-2'-deoxyguanosine) excreted in the urine of patients. All the previously mentioned modifications were analyzed using techniques involving high performance liquid chromatography/electrochemical detection (HPLC/EC) or HPLC/gas chromatography and mass spectroscopy (GC-MS). All patients $(n=46)$ suffered from ovarian cancer and were divided into three groups: G1, G2, and G3, according to the degree of histological malignancy of the neoplasm. In the female patients whose neoplasms showed higher degrees of histological malignancy significantly higher median values of 8-oxoGua and 8-oxodG were found to be excreted in their urine. In the subgroup of patients with G3 feature, both these markers of oxidative stress were almost twice as high as in the subgroup with G1 feature. The results suggest that the oxidative stress in ovarian cancer patients as demonstrated by increased amounts of these modifications in urine may be typical not only for the affected tissue, but also for other tissues and even the whole organism. It is also possible that the accumulation of oxidative stress is proportional to the degree of histological malignancy and depends on histological diagnosis.
\end{abstract}

Keywords: Ovarian Cancer, Oxidative Stress, Oxidative DNA Damage, Histological Diagnosis

\section{Introduction}

Oxidative stress within the body generates numerous DNA lesions which play a significant role in mutagenesis, carcinogenesis, and the aging of the body [1]. One of the most characteristic markers of oxidative stress, a modified DNA base, 8-oxo-7.8-dihydroguanine (8-oxoGua), may play an important role in the process of carcinogenesis in vivo $[2,3]$.

It has generally been accepted that the markers of DNA damage, such as the oxidatively modified base, 8-oxo-7.8dihydroguanine (8-oxoGua) and its nucleotide: 8-oxo-7.8dihydro-2'-deoxyguanosine (8-oxodG), excised from DNA in the process of cellular repair, are excreted in urine in unchanged form without further metabolism [4]. Furthermore, it is a known and accepted fact that certain amounts of oxidative DNA modifications are also present in normal cells [5]. While high levels of the markers of oxidative DNA damage in the urine indicate elevated oxidative stress, they may also reflect a high level of efficiency of the systems that repair these lesions (oxidative stress can be high and the mechanisms responsible for repair eliminate its effects).

Since oxidative stress is closely connected with chronic inflammatory conditions [6], a high level of 8-oxoGua in the urine may reflect the progression of a disease. Indeed, several studies have found that the factors reflecting inflammatory conditions can also be independent prognostic factors $[7,8]$. Additionally, they may stimulate cancerous growth by the suppression of local anti-neoplasm immune responses [9].

Other researchers emphasize the significance of the expression of anti-inflammatory process mediators in response to stress in the process of carcinogenesis [10].

In our previously published paper [11], we demonstrated increased amounts of the oxidative stress markers 8oxoGua and 8-oxodG, excreted in urine, in several types of neoplasms: head and neck cancer $(n=45)$, breast cancer $(n=32)$, colon cancer $(n=25)$, lung cancer $(n=37)$, uterine cancer $(n=15)$, testicular cancer $(n=7)$, prostate cancer 
$(\mathrm{n}=11)$, and gastrointestinal cancer $(\mathrm{n}=11)$.

Some authors have provided information about the role of oxidative stress in patients with ovarian cancer [12]. This study found that the effect of hydroxyl radicals on DNA may play an important role in ovarian cancer pathogenesis while 8-oxodG assay using the immunohistochemicalmethod can be a useful prognostic marker for cases of this type of cancer.

It is worth noting that although the role of oxidative stress in the process of carcinogenesis seems well known, so far no quantitative correlation between oxidative DNA damage and the degree of histological malignancy of neoplasms has been determined

In the current study we have attempted to show the possible correlations based on the amounts of basic oxidative stress markers such as 8-oxoGua and 8-oxodG excreted in urine.

\section{Material and Methods}

\subsection{Patients}

24-hour urinary excretion of 8-oxoGua and 8-oxodG was subjected to analysis prior to oncological treatment in 46 female patients diagnosed with ovarian cancer (the degrees of clinical advancement were III and IV according to FIGO). The entire sample was divided into three subgroups: G1, G2, and G3, according to the degree of histological malignancy of the neoplasms. A detailed clinical characteristic of the patients is presented in Table 1 .

The selection of patients followed the criteria of the group of patients; these included eating habits, age, body weight, and smoking status.

The study was approved by the Medical Ethics Committee of The Collegium Medicum of the Nicolaus Copernicus University in Bydgoszcz, Poland, No 218/2003 (in accordance with Good Clinical Practice, Warsaw 1998), and all the patients gave their informed consent prior to participating in the study.

\subsection{Urine Analysis}

The urinesamplepreparation, HPLC purification, and
GC/MS analysiswereconducted as describedearlier $[13,14]$. In addition to the unequivocal identification of the analyzed compounds and high sensitivity, the use of isotopicallylabeled internal standards compensated for the potential losses of the analyses during sample work-up.

Table 1. Patient Characteristics

\begin{tabular}{lll}
\hline \multicolumn{3}{l}{ No. of Patients } \\
\hline Total & 46 \\
Age, years & \\
Median & 56 \\
Range & $35-71$ \\
ECOG performance status & & \\
$0-1$ & $37(74 \%)$ & \\
$\geq 2$ & $9 \quad(16 \%)$ & \\
& & \\
Ovarian cancer & Stage & Status N+ \\
$(\mathrm{n}=15)$ & $\mathrm{G} 1$ & $\mathrm{n}=5$ \\
$(\mathrm{n}=13)$ & $\mathrm{G} 2$ & $\mathrm{n}=9$ \\
$(\mathrm{n}=14)$ & G 3 & $\mathrm{n}=22$ \\
\hline
\end{tabular}

Abbreviation: ECOG, Eastern Cooperative Oncology Group.

\subsection{Statistical Analysis}

All results are expressed as median (interquartile range). The STATISTICA (version 10) computer software (StatSoft, Inc, Tulsa, OK) was used for the statistical analysis. For normal distribution, variables were analyzed by the Kolmogorov-Smirnov test with Lillefor's correction. Statistical significance was considered at $\mathrm{p}<0.05$.

\section{Results}

Significantly higher amounts of 8-oxoGua and 8-oxodG excreted in the urine within 24 hours were found in those patients with neoplasms having a higher degree of histological malignancy. In the subgroup of patients with G3 feature, the levels of both markers of oxidative stress were almost twice as high as in the subgroup with G1 feature. The detailed results are presented in Table 2.

Table 2. The level of 8-oxoGua and 8-oxodG in the urine, Median (interquartile range), Mean ( $\pm S D$ ).

\begin{tabular}{|c|c|c|c|c|c|c|}
\hline & \multicolumn{3}{|c|}{$\begin{array}{l}\text { Urinary 8-oxoGua } \\
\text { (nmol/mmol creatinine) }\end{array}$} & \multicolumn{3}{|c|}{$\begin{array}{l}\text { Urinary 8-oxodG } \\
\text { (nmol/mmol creatinine) }\end{array}$} \\
\hline & G 1 & G 2 & G 3 & G 1 & G 2 & G 3 \\
\hline $\begin{array}{l}\text { Median } \\
(25 \% \div 75 \%) \\
\text { Mean } \\
( \pm \text { SD) }\end{array}$ & $\begin{array}{l}11.19 \\
(8.89 \div 15.43) \\
11.87 \\
( \pm 4.43)\end{array}$ & $\begin{array}{l}11.98 \\
(10.58 \div 13.04) \\
12.48 \\
( \pm 3.83)\end{array}$ & $\begin{array}{l}23.08 \\
(15.43 \div 28.14) \\
22.46 \\
( \pm 7.98)\end{array}$ & $\begin{array}{l}7.59 \\
(6.79 \div 8.76) \\
7.91 \\
( \pm 2.3)\end{array}$ & $\begin{array}{l}10.47 \\
(9.46 \div 10.97) \\
10.31 \\
( \pm 1.73)\end{array}$ & $\begin{array}{l}13.41 \\
(12.98 \div 17.29) \\
15.12 \\
( \pm 3.58)\end{array}$ \\
\hline $\mathrm{N}$ & 15 & 13 & 14 & 15 & 13 & 14 \\
\hline $\mathrm{p}$ & & $\begin{array}{l}\mathrm{G} 1 \text { vs } \mathrm{G} 2 \\
\mathrm{p}=0.61\end{array}$ & $\begin{array}{l}\text { G1 vs G3 } \\
p=0.003 \\
\text { G2 vs G3 } \\
p=0.0001\end{array}$ & & $\begin{array}{l}\text { G1 vs G2 } \\
p=0.004\end{array}$ & $\begin{array}{l}\mathrm{G} 1 \text { vs } \mathrm{G} 3 \\
\mathrm{p}=0.00001 \\
\mathrm{G} 2 \text { vs G3 } \\
\mathrm{p}=0.0003\end{array}$ \\
\hline
\end{tabular}




\section{Discussion}

In our previous study [11], increased amounts of the oxidative stress markers 8-oxoGua and 8-oxodG were shown to be excreted in the urine of cancer patients when compared with their healthy counterparts. Consequently, with such a diverse profile of tumor location and different natural courses of the disease, it was not possible to determine the exact correlation between the degree of intensification of oxidative stress and the degree of malignancy of the neoplasm. In the present study, we tried to determine the correlation between the degree of histological malignancy of a neoplasm and the quantity of excreted products of oxidative DNA damage.
The results presented in this paper, comparing the amounts of 8-oxoGua and 8-oxodG excreted with urine within twenty-four hours in female patients diagnosed with ovarian cancer, indicate a clear correlation between these amounts and the degree of $\mathrm{G}$ malignancy (Table 2, Figure 1). This significant increase in the studied markers of oxidative DNA damage in the subgroup with G3 feature may reflect the conditions of oxygen shock associated with cancerous disease $[15,16]$. It is also possible that the intensity of oxidative stress is proportional to the degree of malignancy (in this case histological malignancy) and depends on histological diagnosis.

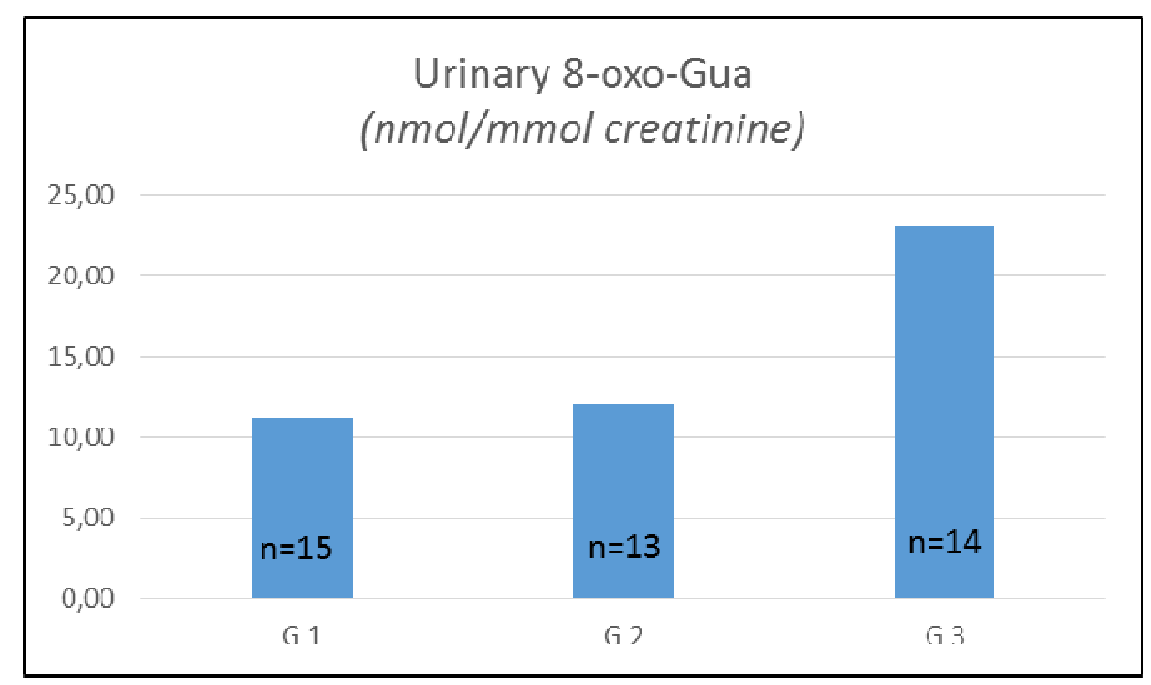

Figure 1. 24-hour urinary excretion of 8-oksodG (A) and 8-oxoGua (B) in the entire sample prior to the treatment (median values), depending on the degree of histological malignancy $G$.

Some authors report a confirmed correlation between the malignancy of the aggressive features of ovarian cancer and specific lymphocyte T-dependent disease markers that may indirectly suggest the significance of oxidative intensity in the progression of neoplastic cell malignancy [17].

So far, several studies have dealt with $[18,19,20,21]$ the analyses of urine 8-oxoGua and 8-oxodG levels in patients with different kinds of cancer and in control groups. The studies showed elevated levels of the analyzed biomolecules in the urine of patients with neoplasms (on average by about $50 \%$ ) as compared with the control group. Each cell contains a certain number of oxidative modifications of nitrogen bases. This is indicative of the balance between the formation of reactive oxygen species (ROS), attacking DNA in the course of numerous metabolic processes, and the removal of damage in these molecules by specific DNA repair enzymes. It seems, however, that the endogenous level of these potentially mutagenic lesions shows a significant inter-individual variability $[6,11,22]$.

In the present study significantly higher values of the oxidatively modified base and nucleotide were found in patients whose neoplasms showed a high degree of histological malignancy, "G3" grade, compared with the group whose tumors had a low "G1" malignancy. Such a significant difference in the quantity of this derivative can be connected with its growth only in the neoplastic cells with a higher degree of malignancy. The ratio of neoplastic cells to the patient's body mass is relatively small. Our results suggest that oxidative stress in patients having neoplasms with a high degree of histological malignancy, represented by increased amounts of these modifications in the urine, may be characteristic not only of the affected tissue, but also of other tissues or the entire body.

\section{Conclusion}

To recap, because of the well-known role of oxidative stress in the process of carcinogenesis, the quantitative correlation between oxidative DNA damage and the degree of histological malignancy of neoplasms has to be determined. We decided to investigate whether the parameters characteristic for oxidative stress/DNA damage depend upon the degree of histological malignancy of the neoplasm. Our results suggest that high levels of basic 
markers of oxidative stress, 8-oxoGua and 8-oxodG, excreted in the urine typically indicate a high degree of advancement of "G3" histological malignancy in patients with ovarian cancer as compared with those diagnosed with "G1" grade, which has a lower degree of malignancy.

\section{Acknowledgments}

I would like to thank Professor Ryszard Olinski of the Department of Clinical Biochemistry, Collegium Medicum, Nicolaus Copernicus University, Bydgoszcz, PL.

\section{References}

[1] Olinski R, Gackowski D, Foksinski M, Rozalski R, Roszkowski K, Jaruga P. Oxidative DNA damage: assessment of the role in carcinogenesis, atherosclerosis and acquired immunodeficiency syndrome. Free Rad Biol Med 2002; 33:192-200.

[2] Tudek B, Speina E. Oxidatively damaged DNA and itsrepair in colon carcinogenesis. Mutat Res2012; 736: 82-92.

[3] Tudek B, Winczura A, Janik J, Siomek A, Foksinski M, Olinski R. Involvement of oxidatively damaged DNA and repair in cancer development and aging. Am J Transl Res 2010; 2: 254-284.

[4] Cooke MS, Olinski R, Loft S. Measurement and Meaning of Oxidatively Modified DNA Lesions in Urine. Cancer Epidemiol Biomarkers Prev 2008; 17(1): 3-14.

[5] Wiseman H, Kaur H, Halliwell B. DNA damage and cancer: measurement and mechanism. Cancer Lett 1995; 93: 113120.

[6] Cooke MS, Olinski R, Evans MD. Does measurement of oxidative damage to DNA have clinical significance? ClinChimActa2006; 365: 30-49.

[7] Leitch EF, Chakrabarti M, Crozier JE, McKee RF, Anderson JH, Horgan PG, McMillan DC. Comparison of the prognostic value of selected markers of the systemic inflammatory response in patients with colorectal cancer. $\mathrm{Br}$ J Cancer2007; 97: 1266-1270.

[8] Roszkowski K, Olinski R. Urinary 8-Oxoguanine as a Predictor of Survival in Patients Undergoing Radiotherapy. Cancer Epidemiol Biomarkers Prev 2012; 21: 629-634.

[9] Szekeres-Bartho J, Polgar B. PIBF: the double edged sword. Pregnancy and Tumor. Am J ReprodImmunol 2010; 64: 7786.

[10] Mor G, Yin G, Chefetz I, Yang Y, Alvero A. Ovarian cancer stem cells and inflammation. Cancer Biology \& Therapy 2011; 11(8): 708-713.

[11] Roszkowski K, Jozwicki W, Blaszczyk P, Mucha-Malecka A, Siomek A. Oxidative damage DNA: 8-oxoGua and 8-oxodG as molecular markers of cancer. Med SciMonit 2011; 17(6): 329-333.
[12] Karihtala P, Soini Y, Vaskivuo L, Bloigu R, Puistola U. DNA adduct 8-hydroxydeoxyguanosine, a novel putative marker of prognostic significance in ovarian carcinoma. Int $\mathrm{J}$ GynecolCancer 2009; 19(6): 1047-1051.

[13] Gackowski D, Rozalski R, Roszkowski K, Jawien A, Foksinski M, Olinski R. 8-Oxo-7,8-dihydroguanine and 8oxo-7,8-dihydro-20-deoxyguanosine levels in human urine do not depend on diet. Free Radic Res 2001; 35: 825-832.

[14] Rozalski R, Gackowski D, Roszkowski K, Foksinski M, Olinski R. The level of 8-hydroxyguanine, a possible repair product of oxidative DNA damage, is higher in the urine of cancer patients than in control subjects. Cancer Epidemiol Biomarkers Prev 2002; 11: 1072-1075.

[15] Cooke MS, Rozalski R, Dove R, Gackowski D, Siomek A, Evans MD, Oliński R. Evidence for attenuated cellular 8oxo-7,8-dihydro-29-deoxyguanosine removal in cancer patients. BiolChem 2006; 387(4): 393-400.

[16] Roszkowski K, Gackowski D, Rozalski R, Dziaman T, Siomek A, Guz J, Szpila A, Foksinski M and Olinski R. Small field radiotherapy of head and neck cancer patients is responsible for oxidatively damaged DNA/oxidative stress on the level of a whole organism. Int J Cancer 2008; 123: 1964-1967.

[17] Sonoda K, Miyamoto S, Yotsumoto F, Yagi H, Nakashima $\mathrm{M}$, Wtanabe T, Nakano H. Clinical significance of RCAS1 as a biomarker of ovarian cancer. Oncology Reports 2007; 17: 623-628.

[18] Siomek A, Tujakowski J, Gackowski D, Rozalski R, Foksinski M, Dziaman T, Roszkowski $\mathrm{K}$ and Olinski R. Severe oxidatively damaged DNA after cisplatin treatment of cancer patients. Int J Cancer 2006; 119: 2228-2230.

[19] Chiou CC, Chang PY, Chan EC, Wu TL, Tsao KC, Wu JT. Urinary 8-hydroxydeoxyguanosine and its analogs as DNA marker of oxidative stress: development of an ELISA and measurement in both bladder and prostate cancers. ClinChimActa 2003; 334(1-2): 87-94.

[20] Loft S, Svoboda P, Kawai K, Kasai H, Sørensen M, Tjønneland A, Vogel U, Møller P, Overvad K, RaaschouNielsen O. Association between 8-oxo-7,8-dihydroguanine excretion and risk of lung cancer in a prospective study. Free RadicBiol Med 2012; 52(1): 167-172.

[21] Postawski K, Przadka-Rabaniuk D, Piersiak T. 8-oxo-7,8dihydroguanine level - the DNA oxidative stress marker recognized by fluorescence image analysis in sporadic uterine adenocarcinomas in women. Ginekol Pol 2013; 84(1): 44-50.

[22] Maynard S, Schurman SH, Harboe C, de Souza-Pinto NC, Bohr VA. Base excision repair of oxidative DNA damage and association with cancer and aging. Carcinogenesis 2009; 30(1): 2-10. 